\title{
The Role of Acute-Phase Reactants in Determining Bacteremia and Evaluation of Diagnostic Benefits of Cultures in Cellulitis Cases
}

\author{
• ㅈ Kübra Demir Önder, • Nefise Öztoprak, • Filiz Kızılateş, \\ [ Ayşegül Seremet Keskin
}

Department of Infectious Disease and Clinical Microbiology, University of Health Sciences Antalya Training and Research Hospital, Antalya, Turkey

Submitted: 00.00 .0000 Accepted: 00.00 .0000

Correspondence: Kübra Demir Önder Sağlık Bilimleri Üniversitesi Antalya Eğitim ve Araştırma Hastanesi, Enfeksiyon Hastalıkları Kliniği, Antalya, Turkey

E-mail:dr_kubrademir@hotmail.com

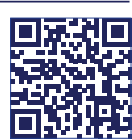

Keywords: Acute phase reactants; bacteremia; cellulitis; soft tissue infection; culture.

\begin{abstract}
Objective: This study aims to investigate the relationship between bacteremia and the level of acute phase reactants in cellulite cases and to evaluate the value of blood culture and tissue/wound/abscess cultures in determining causal microorganism.
\end{abstract}

Methods: The adult patients were included in this study, who were hospitalized with a diagnosis of cellulitis between January I, 20I5, and December 3I, 20I6. Patients' medical records revealed from computer based hospital system, retrospectively. Patients with diabetic foot infections, decubitus infections, cellulite accompanying shingles and other concomitant system infections were excluded from this study. Before antibiotic treatment, patient's body temperature, leukocyte count, c reactive protein level, erythrocyte sedimentation rate, culture results, antibiotic treatment before hospitalization, empirical antibiotic treatment in hospital, treatment duration, comorbidities and clinical response data were collected.

Results: There were 194 patients in this study. Blood cultures collected from 143 patients before antibiotic treatment. Nine of I43 (6.3\%) patient's blood cultures were positive. On the other hand, results of the tissue/wound cultures were positive in 17 of the 35 cases (48.6\%). Mean white blood cell count at the first admission was $13.9 \times 10^{3} / \mathrm{mm}^{3}$ in non-bacteremic group and $15.2 \times 10^{3} / \mathrm{mm}^{3}$ in bacteremic group. Mean C-reactive protein level at the first admission was $148 \mathrm{mg} / \mathrm{L}$ in non-bacteremic group and $164 \mathrm{mg} / \mathrm{L}$ in bacteremic group. There was no statistical significance between these two acute phase marker and bacteremia in cellulitis cases. However, mean erythrocyte sedimentation rate was 92 vs $56.5 \mathrm{~mm} / \mathrm{h}$ respectively in bacteremic and non-bacteremic patient $(p=0.03)$.

Conclusion: In the cases of cellulitis, blood culture did not provide sufficient clinical benefit for the etiology even the presence of fever. It was concluded that taking culture samples from infection site, such as abscess, wound and tissue culture, would be more useful for identification of the etiologic agent.

\section{INTRODUCTION}

Microbial invasion of the skin and subcutaneous soft tissue is defined as skin and soft tissue infection. These infections may occur in many different clinical forms. Of these, cellulitis is a clinical entity that occurs with the involvement of the deep layers of the dermis and/or subcutaneous tissue layers, with indeterminated borders, redness, swelling and increased temperature. ${ }^{[1]}$

The diagnosis of cellulitis is based on the morphological features of the lesion and clinical findings. ${ }^{[2]}$ Generally, empirical treatment is used. In cases with cellulitis, detection rates of causative agents in blood cultures are below 5\%. ${ }^{[3,4]}$ Taking an aspiration culture with a needle is not a routine approach in the diagnosis of cellulitis. ${ }^{[2]}$ However, in different studies performed to investigate the agent microorganism with needle aspiration, the rates of demonstrating the pathogenic agent are much higher than the detection rates based on blood culture positivity. ${ }^{[5-7]}$ Tissue cultures are important in the diagnosis of cellulitis, while swab cultures are inadequate in determining skin colonization, and isolating the causative pathogen. ${ }^{[8]}$

White blood cell counts, C-reactive protein (CRP) levels and erythrocyte sedimentation rates increase in parallel 
with the severity of the infection. In our study, we aimed to evaluate the levels of these parameters in the case of bacteremia and the place of the cultures obtained from blood and the infection sites, such as tissue, wound, pus, aspiration culture, in showing the etiological agent.

\section{MATERIALS AND METHODS}

Between January I, 2015, and December 3I, 2016, the medical records of patients aged 18 and over who were diagnosed with cellulitis in our clinic were analyzed retrospectively. Patients with diabetic foot infections, decubitus infections, cellulitis accompanying shingles and other systemic infections were excluded from this study. Patients' pre-treatment body temperature, leukocyte count, CRP and erythrocyte sedimentation rate, blood cultures, tissue and wound cultures, antibiotics taken before hospitalization, empirical antibiotic treatments and duration of treatment, comorbid diseases and clinical responses were recorded.

In the recurrent episodes of cellulitis in the same patient, each application was taken as a new episode. Since the procalcitonin test, which is a good and more specific indicator concerning bacteremia, was not studied in our hospital at that time, erythrocyte sedimentation rates, CRP levels and white blood cell counts were measured and evaluated.

\section{Statistical evaluation}

Descriptive statistics were presented with percentage, mean, standard deviation, median, minimum and maximum values. The normality assumption was checked using the Shapiro-Wilk Test. In the analysis of the difference between the numerical data of the two groups, Independent Samples- t-test (Independent Two-Sample t-test) was used when the data fit the normal distribution and MannWhitney $U$ test was used for the data with the nonnormal distribution. Relationships between numerical data were evaluated using the non-parametric Spearman Correlation Test and parametric Pearson Correlation Test.

Pearson Chi-Square (Pearson Chi-Square) test was used in the analysis of categorical data. The diagnostic positivity limit value (cut-off value) of the acute phase reactants was evaluated by ROC analysis. Analyzes were performed with the SPSS 23.0 program. $P<0.05$ was considered statistically significant.

\section{RESULTS}

Demographic and clinical information of 194 patients diagnosed with cellulitis, which meet the inclusion criteria, are given in Table I.

It was determined that blood cultures were obtained from I 43 patients before treatment and only in nine $(6.30 \%)$ of them bacterial growth was detected. However, in tissue, wound, pus cultures of 17 (48.6\%) out of 35 cases, bacte-
Table I. Demographic and clinical characteristics of the patients

\begin{tabular}{|c|c|c|}
\hline Variables & $n=194$ & $(100 \%)$ \\
\hline \multicolumn{3}{|l|}{ Age } \\
\hline Median (min-max) & 61 & $(19-92)$ \\
\hline \multicolumn{3}{|l|}{ Gender, n (\%) } \\
\hline Male & 125 & $(64.4)$ \\
\hline Female & 69 & $(35.6)$ \\
\hline \multicolumn{3}{|l|}{ Duration of hospitalization/days } \\
\hline Median (min-max) & 7 & $(1-57)$ \\
\hline \multicolumn{3}{|l|}{ Most frequently affected region, $n$ (\%) } \\
\hline Lower extremities & 97 & $(50.0)$ \\
\hline \multicolumn{3}{|l|}{ Types of hospital admition, $n(\%)$} \\
\hline From emergency service & 120 & $(61.9)$ \\
\hline From outpatient clinics & 69 & $(35.6)$ \\
\hline Transfer from another service & 5 & $(2.6)$ \\
\hline \multicolumn{3}{|l|}{ Comorbidities, n (\%) } \\
\hline Tinea pedis, onychomiycozis & 80 & $(4 I .2)$ \\
\hline Diabetes mellitus & 64 & $(33.0)$ \\
\hline Peripheral vascular/lymphatic disease & 53 & $(27.3)$ \\
\hline Implant/prosthesis/graft & 26 & $(13.4)$ \\
\hline Malignancy & 19 & $(9.8)$ \\
\hline Immobility & 14 & (7.2) \\
\hline Chronic renal failure & 13 & $(6.7)$ \\
\hline Congestive heart failure & 12 & $(6.2)$ \\
\hline \multicolumn{3}{|l|}{ (associated with pretibial edema) } \\
\hline Immune suppression & 9 & $(4.6)$ \\
\hline IV drug addiction & 8 & (4.I) \\
\hline Obesity & 6 & $(3.1)$ \\
\hline Alcoholism & I & $(0.5)$ \\
\hline
\end{tabular}

rial growth was observed. Both blood, and tissue, wound and pus cultures were obtained in 17 patients, and in 15 out of these 17 cases, bacterial growth was detected only in tissue, wound and pus cultures, any pathogen was not reproduced in the blood cultures of these patients. In two of these cases, bacterial growth was seen only in blood cultures. The causative agents isolated from blood, tissue, wound, and pus cultures are shown in Table 2.

It was observed that 80 patients (41.2\%) used antibiotics before hospitalization. The most frequently used antibiotherapy in this group was amoxicillin- clavulanate $(34.6 \%)$, followed by amoxicillin- clavulanate + ciprofloxacin (16\%). There was no statistically significant difference between the groups that used and did not use antibiotics before hospitalization regarding bacterial pathogen identification rates in blood and tissue, wound, and pus cultures $(p=0.922$ and $p=0.728)$. It was remarkable that $28.7 \%$ of the patients who used, and $48.2 \%$ of the patients who did not use antibiotics before hospitalization had a fever $(\mathrm{p}=0.006)$.

Seventy-eight (40.2\%) patients had fever at first admission. When the average CRP values were determined at first admission among patients with and without fever, the average CRP value was found to be significantly higher in 
Table 2. Pathogenic microorganisms isolated from blood, tissue, wound and pus cultures

\begin{tabular}{|c|c|c|}
\hline Patients & Blood culture & Tissue, wound, pus culture \\
\hline I & No growth & $\begin{array}{l}\text { Methicillin-sensitive Staphylococcus aureus + } \\
\text { Streptococcus pyogenes }\end{array}$ \\
\hline 2 & Group G Streptococci & Culture not performed \\
\hline 3 & No growth & Methicillin-resistant coagulase negative Staphylococci \\
\hline 4 & No growth & Methicillin-sensitive Staphylococcus aureus \\
\hline 5 & No growth & Methicillin-sensitive Staphylococcus aureus \\
\hline 6 & No growth & $\begin{array}{l}\text { Methicillin-sensitive Staphylococcus aureus }+ \\
\text { Methicillin-resistant coagulase negative Staphylococci }\end{array}$ \\
\hline 7 & $\begin{array}{l}\text { Methicillin-sensitive Staphylococcus aureus+ } \\
\text { Streptococcus agalactiae }\end{array}$ & Culture not performed \\
\hline 8 & Culture not performed & Group B Streptococci \\
\hline 9 & Methicillin-sensitive Staphylococcus aureus & Culture not performed \\
\hline 10 & No growth & $\begin{array}{l}\text { Morganella morganii }+ \text { Enterococcus fecalis }+ \\
\text { Methicillin-resistant coagulase negative Staphylococci }\end{array}$ \\
\hline II & Proteus vulgaris & Not available \\
\hline 12 & No growth & Methicillin-sensitive Staphylococcus aureus \\
\hline 13 & No growth & Methicillin-sensitive Staphylococcus aureus \\
\hline 14 & No growth & Methicillin-sensitive Staphylococcus aureus \\
\hline 15 & No growth & Methicillin-sensitive Staphylococcus aureus \\
\hline 16 & No growth & Methicillin-resistant coagulase negative Staphylococci \\
\hline 17 & No growth & Methicillin-resistant Staphylococcus aureus \\
\hline 18 & Streptococcus pyogenes & Culture not performed \\
\hline 19 & Streptococcus pyogenes & Culture not performed \\
\hline 20 & Streptococcus parasanguinis & No growth \\
\hline 21 & Methicillin-resistant coagulase negative Staphylococci & Culture not performed \\
\hline 22 & No growth & Methicillin-sensitive Staphylococcus aureus \\
\hline 23 & No growth & Streptococcus constellatus \\
\hline 24 & No growth & Methicillin-resistant coagulase negative Staphylococci \\
\hline 25 & Methicillin-sensitive Staphylococcus aureus & No growth \\
\hline 26 & Culture not performed & Methicillin-resistant Staphylococcus aureus \\
\hline
\end{tabular}

patients with fever (I $15.7 \mathrm{mg} / \mathrm{L}$ vs $171.3 \mathrm{mg} / \mathrm{L}, \mathrm{p}<0.00 \mathrm{I}$, respectively). From 69 of 78 patients with fever at admission, samples were obtained for blood culture and in five (7.2\%) of them bacterial growth was detected, while in four of $74(5.4 \%)$ patients without fever at admission, bacterial growth was observed in the blood cultures $(p=0.650)$.

When all cases were evaluated, the mean values for white blood cell count, CRP and erythrocyte sedimentation rate were $13.2 \pm 5.8 \times 10^{3} / \mathrm{mm}^{3}, \quad 138.07 \pm 96.6 \mathrm{mg} / \mathrm{L}$, and $55.05 \pm 33.01 \mathrm{~mm} / \mathrm{h}$, respectively.

Mean number of white cells (WBC) at first admission were $13.9 \pm 6.2 \times 10^{3} / \mathrm{mm}^{3}$ in non-bacteremic, and $15.2 \pm 8.5 \times 10^{3} /$ $\mathrm{mm} 3$ in bacteremic patients $(p=0.702)$ and WBC counts were, $16.7 \pm 9.3 \times 10^{3} / \mathrm{mm}^{3}$ and $13.09 \pm 5.9 \times 10^{3} / \mathrm{mm}^{3}$ in $\mathrm{pa}$ tients whose wound, tissue, pus cultures did, and did not demonstrate the presence of bacterial growth, respectively $(p=0.129)$.

The mean CRP values at the first admission were $148 \pm 100$ $\mathrm{mg} / \mathrm{L}$ in the non-bacteremic group, and $164 \pm 84 \mathrm{mg} / \mathrm{L}$ in the bacteremic group, without any statistically significant dif- ference between groups $(p=0.839)$. The mean CRP value at first admission was $145 \pm 73 \mathrm{mg} / \mathrm{L}$ in patients whose wound, tissue, pus cultures were positive, while it was $169 \pm 93 \mathrm{mg} / \mathrm{L}$ in whom wound, tissue, pus cultures were negative $(p=0.438)$.

The mean erythrocyte sedimentation rates at first admission were $92 \pm 27 \mathrm{~mm} / \mathrm{h}$ and $56.5 \pm 33 \mathrm{~mm} / \mathrm{h}$ in the groups with and without bacterial growth in their blood cultures $(p=0.03)$. In addition, it was found that sedimentation values of $67.5 \mathrm{~mm} / \mathrm{h}$ and above were more significant concerning showing bacteremia by ROC analysis. In the group with bacterial growth in tissue, wound, pus cultures mean sedimentation rate at first admission was found to be higher than the culture negative group, without any statistically significant difference between both groups $(6 I \pm 35$ $\mathrm{mm} / \mathrm{h}$ and $54 \pm 25 \mathrm{~mm} / \mathrm{h}, \mathrm{p}=0.726$, respectively). Mean CRP values, WBC counts, and sedimentation rates in groups with and without bacterial growth in their blood, tissue, wound, and pus cultures are shown in Table 3.

Cellulitis started spontaneously in 142 (72\%) of the pa- 
Table 3. Mean white blood cell counts, C-reactive protein values, and erythrocyte sedimentation rates

\begin{tabular}{|c|c|c|c|c|c|c|c|}
\hline & $\begin{array}{c}\text { Overall } \\
(n=194)\end{array}$ & $\begin{array}{l}\text { Patients without } \\
\text { bacterial growth } \\
\text { in their blood } \\
\text { cultures }(n=134)\end{array}$ & $\begin{array}{l}\text { Patients with } \\
\text { bacterial growth } \\
\text { in their blood } \\
\text { cultures }(n=9)\end{array}$ & $\mathbf{p}$ & $\begin{array}{l}\text { Patients without } \\
\text { bacterial growth } \\
\text { in their tissue, } \\
\text { wound and pus } \\
\text { cultures }(n=18)\end{array}$ & $\begin{array}{l}\text { Patients with } \\
\text { bacterial growth } \\
\text { in their tissue, } \\
\text { wound and pus } \\
\text { cultures }(n=I 7)\end{array}$ & $\mathbf{p}$ \\
\hline $\begin{array}{l}\text { Mean white blood } \\
\text { cell counts } \\
\text { at first admition } \\
\left(\times 10^{3} / \mathrm{mm}^{3}\right)\end{array}$ & $13.2 \pm 5.8$ & $13.9 \pm 6.2$ & $15.2 \pm 8.5$ & 0.702 & $13.09 \pm 5.9$ & $16.7 \pm 9.3$ & 0.129 \\
\hline $\begin{array}{l}\text { Mean C-reactive } \\
\text { protein values at first } \\
\text { admition }(\mathrm{mg} / \mathrm{L})\end{array}$ & $138 \pm 96$ & $148 \pm 100$ & $164 \pm 84$ & 0.839 & $169 \pm 93$ & $145 \pm 73$ & 0.438 \\
\hline $\begin{array}{l}\text { Mean sedimentation } \\
\text { rates at first } \\
\text { admition }(\mathrm{mm} / \mathrm{h})\end{array}$ & $55 \pm 33$ & $56 \pm 33$ & $92 \pm 27$ & 0.030 & $54 \pm 25$ & $61 \pm 35$ & 0.726 \\
\hline
\end{tabular}

tients without any causative factors as trauma, burn, open wound, insect bite but tineapedis and/or onychomycosis were detected in $44.4 \%$ of these patients.

It was observed that ampicillin-sulbactam (64.9\%) and tigecycline $(22.7 \%)$ were started mostly as an empirical treatment in hospitalized patients and the initial empirical antibiotherapy was continued without changing in 148 (76.3\%) patients. The average duration of antibiothearpy was $9.3 \pm 6.6$ days, and 185 (95.4\%) patients were administered oral follow-up treatment after discharge.

During follow-up, $4 \mathrm{I}$ patients (2I.1\%) developed complications, such as abscess, necrosis, fasciitis or need for surgical intervention, and the length of hospital stay was found to be longer in these patients than the patients without complications $(14 \pm 10$ and $8 \pm 4$ days, $\mathrm{p}<0.001$, respectively). Osteomyelitis accompanied cellulitis in the followup of 14 patients (7.2\%).

\section{DISCUSSION}

In the literature, rates of blood culture positivity have been reported to be below $5 \%$ in cases of cellulitis derived from different sources. ${ }^{[3,4]}$ In our study, this rate was found to be $6.3 \%$. Although in the 2014 skin and soft tissue infections guidelines of Infectious Diseases Society of America (IDSA), obtaining routine blood, wound aspiration, skin biopsy or swab cultures for the diagnosis of cellulitis are not recommended, ${ }^{[9]}$ in different studies conducted to determine the agent with needle aspiration, it is seen that the rates of identifying the bacterial pathogen are much higher than the rates estimated based on blood culture positivity. ${ }^{[5-7]}$ Similarly, in our study, the rate of bacterial growth in blood cultures of 143 patients was found to be only $6.3 \%$, Although culture material could be obtained from a smaller number $(n=35)$ of patients, the active microorganism could be demonstrated in $48.6 \%$ of tissue, wound and pus cultures.

This result shows that in cases presenting with cellulitis, isolation of the microorganism from the infection site, such as tissue, wound, and pus, is more useful than the blood culture. Because skin colonization and pathogenic microorganism cannot be distinguished in superficial swab cultures, tissue cultures are more valuable in demonstrating the active microorganisms. ${ }^{[8]}$

When the effects of empirical antibiotic use before hospitalization on culture results were evaluated, there was no statistically significant difference between the groups using and not using antibiotics regarding rates of bacterial growth in blood and tissue, wound, and pus culture media $(p=0.922$ and $p=0.728$ ). Fever was detected in $28.7 \%$ of the patients who used, and in $48.2 \%$ of the patients who did not use antibiotics before hospitalization with a statistically significant difference between groups $(p=0.006)$. It was thought that fever at admission decreased with empirical oral antibiotic treatment instituted before hospitalization.

Blood cultures were obtained from 69 of 78 patients with fever at admission and in five of them (7.2\%), bacterial growth was seen in their blood cultures, and in four of 74 (5.4\%) afebrile patients bacterial growth was observed in blood cultures. These results suggest that the presence of fever is not an adequate clinical finding to demonstrate bacteremia.

Mean WBC counts at first presentation were $13.9 \pm 6.2 \times 10^{3} / \mathrm{mm}^{3}$ in non-bacteremic, and $15.2 \pm 8.5 \times 10^{3} /$ $\mathrm{mm}^{3}$ in bacteremic patients $(p=0.702)$, and WBC counts were $16.7 \pm 9.3 \times 10^{3} / \mathrm{mm}^{3}$, and $13.09 \pm 5.9 \times 10^{3} / \mathrm{mm}^{3}$ in patients with, and without bacterial growth in wound, tissue, and pus culture media, respectively $(p=0.129)$. Mean CRP values at first admission were $148 \pm 100 \mathrm{mg} / \mathrm{L}$ in the non-bacteremic and $164 \pm 84 \mathrm{mg} / \mathrm{L}$ in the bacteremic group, without any significant intergroup difference $(p=0.839)$. Also, at first presentation, mean CRP values were $145 \pm 73$ $\mathrm{mg} / \mathrm{L}$, and $169 \pm 93 \mathrm{mg} / \mathrm{L}$ in patients whose wound, tissue, pus culture did and did not reveal the presence of bacterial growth $(p=0.438)$. 
Although mean CRP values and white blood cell counts did not differ significantly between groups with and without bacterial growth in their blood, wound, tissue, pus cultures, it is noteworthy that the mean erythrocyte sedimentation rate was higher in bacteremic patients than in non-bacteremic patients $(92 \pm 27 \mathrm{~mm} / \mathrm{h}$ and $56.5 \pm 33 \mathrm{~mm} / \mathrm{h}$, respectively: $p=0.03$ ). In addition, given that although not statistically significant, mean sedimentation rate was higher at first presentation in the group with bacterial growth in their tissue, wound, and pus cultures compared with those without bacterial growth $(61 \mathrm{~mm} / \mathrm{h}$ and $54 \mathrm{~mm} / \mathrm{h}$, respectively) is also a valuable finding, Especially values of 67.5 $\mathrm{mm} / \mathrm{h}$ and over were found to be significant concerning showing bacteremia by ROC analysis.

In another study comparing the diagnostic values of CRP, sedimentation and white blood cell counts in bacteremia, among 265 pediatric cases with bone, and joint infections, mean CRP values in bacteremic and non-bacteremic groups were $93 \pm 5$ and $77 \pm 5, p<0.05$, respectively; While mean white blood cell counts were $11900 \pm 500$ and 13 $800 \pm 700$, respectively, $p<0.05$, without any significant difference concerning mean sedimentation rates between the bacteremic: and non-bacteremic groups $(53 \pm 2$ and $47 \pm 3$, respectively, $p=0.10)$. ${ }^{[1]}$

The development of cellulitis is mostly induced by the presence of skin trauma, open wound or fissure..$^{[2]}$ In our study, considering the initial form of cellulitis, cellulitis started spontaneous in 142 (72\%) of the patients without causative factors as trauma, burn, open wound, insect bite, and it was found that approximately half of these patients (44.4\%) had tinea pedis and/or onychomycosis. Similarly, in a study conducted in our country, in which risk factors were evaluated in patients with cellulitis localized at a lower extremity, tinea pedis was detected in $36.4 \%$ of cases and this rate increased to $72.7 \%$ in cases of recurrent cellulitis. ${ }^{[1]}$

In our study, it was found that ampicillin-sulbactam (64.9\%) and tigecycline $(22.7 \%)$ were started mostly as empirical treatment in hospitalized patients and the mean parenteral antibiotic treatment period was $9.3 \pm 6.6$ days. In two separate studies conducted with cellulitis patients in our country, the most commonly used antibiotic in the treatment of cellulitis was found to be ampicillin-sulbactam, while mean parenteral treatment times were $17 \pm 12.4$ days in one, and 3-7 days in the other study. ${ }^{[1,12]}$ Although the basic treatment approach is similar, it is seen that antibiotic treatment times may differ among centers.

During the follow-up, $4 \mathrm{I}$ patients (2I.I\%) developed complications, such as abscess, necrosis, fasciitis or need for surgical intervention, and the length of hospital stay was found to be longer in these patients than the patients without complications ( $14 \pm 10$ and $8 \pm 4$ days, respectively $\mathrm{p}<0.00 \mathrm{I}$ ). In another study conducted in our country, it was stated that $6.5 \%$ of the patients with a diagnosis of cellulitis developed an abscess as a complication, but there was no significant difference in the treatment response compared to the group without complications. ${ }^{[1]}$
Cellulitis may rarely arise from the spread of underlying osteomyelitis. ${ }^{[2]}$ In our study, advanced radiological imaging modalities revealed that osteomyelitis accompanied cellulitis in 14 patients $(7.2 \%)$ hospitalized with a diagnosis of cellulitis.

In conclusion, it was determined that increased erythrocyte sedimentation rate was found to be a valuable marker in bacteremic cases with cellulitis, and as a result of the ROC analysis, sedimentation rates of $67.5 \mathrm{~mm} / \mathrm{h}$ and above were more significant concerning indicating bacteremia. In addition, considering the low rate of bacterial growth in blood cultures, it is thought that even if there is fever in patients presenting with the clinical manifestations of cellulitis, taking tissue, wound, pus cultures from the site of cellulitis instead of blood cultures will provide a diagnostic advantage, as well as reducing the loss of labor, cost and time. However, considering the low number of samples demonstrating bacterial growth in cultures in our study, new studies to be conducted in greater number of cases with cellulitis are needed.

Ethics Committee Approval

Approved by the local ethics committee (date: 30.07 .2017 ; no: 6/14.2017- 083).

Peer-review

Internally peer-reviewed.

Authorship Contributions

Concept: K.D.Ö.; Design: N.Ö., A.S.K.; Supervision: K.D.Ö., F.K.; Fundings: K.D.Ö.; Materials: K.D.Ö.; Data: K.D.Ö., A.S.K.; Analysis: K.D.Ö.; Literature search: F.K., N.Ö., A.S.K.; Writing: K.D.Ö.; Critical revision: N.Ö., F.K.

Conflict of Interest

None declared.

\section{REFERENCES}

1. Ki Vi, Rotstein C. Bacterial skin and soft tissue infections in adults: A review of their epidemiology, pathogenesis, diagnosis, treatment and site of care. Can J Infect Dis Med Microbiol 2008;19:173-84. [CrossRef]

2. Swartz MN. Clinical practice. Cellulitis. N Engl J Med 2004;350:904-12. [CrossRef]

3. Perl B, Gottehrer NP, Raveh D, Schlesinger Y, Rudensky B, Yinnon AM. Cost-effectiveness of blood cultures for adult patients with cellulitis. Clin Infect Dis 1999;29:1483-8. [CrossRef]

4. Sukumaran V, Senanayake S. Bacterial skin and soft tissue infections. Aust Prescr. 2016;39:159-63. [CrossRef]

5. Sachs MK. The optimum use of needle aspiration in the bacteriologic diagnosis of cellulitis in adults. Arch Intern Med 1990;150:1907-12.

6. Duvanel T, Auckenthaler R, Rohner P, Harms M, Saurat JH. Quantitative cultures of biopsy specimens from cutaneous cellulitis. Arch Intern Med 1989;149:293-6. [CrossRef]

7. Sigurdsson AF, Gudmundsson S. The etiology of bacterial cellulitis as determined by fine-needle aspiration. Scand J Infect Dis 1989;21:537-42. [CrossRef]

8. Slater RA, Lazarovitch T, Boldur I, Ramot Y, Buchs A, Weiss M, et al. Swab cultures accurately identify bacterial pathogens in diabetic foot wounds not involving bone. Diabet Med 2004;21:705-9. [CrossRef]

9. Stevens DL, Bisno AL, Chambers HF, Dellinger EP, Goldstein EJ, Gorbach SL, et al. Practice Guidelines for the Diagnosisand Manage- 
ment of Skin and Soft Tissue Infections: 2014 Update by the Infectious Diseases Society of America. Clin Infect Dis 2014;59:147-59.

10. Pääkkönen M, Kallio MJ, Kallio PE, Peltola H. C-reactive protein versus erythrocyte sedimentation rate, White blood cell count and alkaline phosphatase in diagnosing bacteraemia in bone and joint infections. J Paediatr Child Health 2013;49:E189-92. [CrossRef]
11. Mehdi L, Ekinci AP, Baykal C. Retrospective Evaluation of Risk Factors and Response in Treatment among Hospitalized Patients with Lower-Extremity Cellulitis. Turk J Dermatol 2016;10:59-64.

12. Turhan Ö, Saba R, Öngüt G, ałçıın AN, Latife Mamıkoğlu L. Bir üniversite hastanesinde izlenen 68 selülit olgusunun değerlendirilmesi. Klimik Dergisi 2006;19:114-6.

\section{Selülit Olgularında Akut Faz Reaktanlarının Bakteremiyi Belirlemedeki Yeri ve Kültürlerin Tanısal Yararının Değerlendirilmesi}

Amaç: Kan kültürlerinin yaklaşık \%5 kadarında üreme gösterilebilen selülit olgularında olası baktereminin tedavi öncesi akut faz reaktanlarının düzeyi ile ilişkisinin araştııılması ve kan kültürü ile doku/yara/apse kültürlerinin karşılaştıılarak etken mikroorganizmayı göstermedeki yerinin değerlendirilmesi amaçlandı.

Gereç ve Yöntem: I Ocak 2015 ve 3I Aralık 2016 tarihleri arasında enfeksiyon hastalıkları ve klinik mikrobiyoloji kliniğinde selülit tanısı ile yatan 18 yaş ve üzeri hastaların medikal kayıtları hastane otomasyon sistemi üzerinden geriye dönük olarak incelendi. Diyabetik ayak enfeksiyonları, dekübit enfeksiyonları, zonaya eşlik eden selülitler ve eşlik eden başka sistem enfeksiyonları olan hastalar çalışmaya dahil edilmedi. Hastaların tedavi öncesi vücut ısısı, lökosit sayısı, C-reaktif protein ve eritrosit sedimantasyon hızı, kültür sonuçları, yatış öncesi aldıkları antibiyotikler, yatışlarında başlanan empirik tedaviler, tedavi süreleri, komorbid hastalıkları ve klinik yanıtları kaydedildi.

Bulgular: Çalışmaya 194 hasta dahil edildi. Yüz kırk üç hastadan tedavi öncesi kan kültürü alındığı ve bunlardan sadece dokuzunda (\%6.30) üreme olduğu saptandı. Buna karşlık doku/ yara kültürü alınan 35 olgunun I7'sinde (\%48.6) üreme olduğu görüldü. İlk başvurudaki ortalama beyaz küre sayısı bakteremik olmayan hastalarda $13.9 \times 10^{3} / \mathrm{mm}^{3}$ iken, bakteremik hastalarda $15.2 \times 10^{3} / \mathrm{mm}^{3}$ idi. Illk başvurudaki ortalama C-reaktif protein değeri ise bakteremik olmayan grupta $148 \mathrm{mg} / \mathrm{L}$ iken, bakteremik grupta $164 \mathrm{mg} / \mathrm{L}$ saptandı. Ancak her iki parametre için de fark istatistiksel olarak anlamlı bulunmadı. Bununla birlikte ilk başvuruda ortalama eritrosit sedimantasyon hızı kanda üreme olmayan ve olan grupta sırasıyla $56.5 \mathrm{~mm} / \mathrm{h}$ ve $92 \mathrm{~mm} / \mathrm{h}$ olarak bulundu ( $p=0.03$ ).

Sonuç: Selülit olgularında başvuruda ateş olsa bile kan kültürünün etiyolojiye yönelik yeterli klinik fayda sağlamadı̆ı; bunun yerine apse, yara, bül sıvısı, doku kültürü gibi enfeksiyon bölgesinden kültür örneği alınmasının etiyolojik ajanı göstermede daha yararlı olacağı kanısına varıldı. Laboratuvar göstergelerden eritrosit sedimantasyon hızı yükseklï̆inin özellikle $67.5 \mathrm{~mm} / \mathrm{h}$ ve üzeri değerlerin bakteremiyi işaret etmesi açısından daha anlamlı olduğu saptandı.

Anahtar Sözcükler: Akut faz reaktanı; bakteremi; kültür; selülit; yumuşak doku enfeksiyonu. 